\title{
Challenges of Technological Entrepreneurship in Africa: The Case of Tunisia
}

Walid Ghodbane*

Department of Management Science, University of Tunis, Tunisia

\begin{abstract}
Technology parks are a strategic tool to spill over knowledge and skills. The rise of technology parks around the world and especially in developing countries, has addressed concerns on the technopreneurial activity and its impact on developing locations and regions, especially in developing countries in Africa, where private and public sector are joining efforts to create a sustainable ecosystem for technology entrepreneurs. Hence, numbers of challenges are facing Africa, particularly the cross-cultural factors and the ICT infrastructure. This research was conducted on Technology Park EI Ghazala in Tunisia. We will try to assess the impact of cross-cultural variables such as age, communication and social networks influence on prospective technology entrepreneurs.
\end{abstract}

Keywords: Entrepreneurship; Technopreneurial; Technology Park El Ghazala; Tunisia

\section{JEL Classification: I22, I25}

\section{Introduction}

The recent change in economic and managerial thinking has led to questions relating to the context of entrepreneurship in light of the radical change in the global economy, as well as the development of science and technology. This scenario has opened up new opportunities and stressed on the restatement of the prosperity principles on the basis of the new vision of the global economy.

Porter's studies [1-3] show that a well-known strategy for global competition is recognizing that science and technology are central aspects of excellence and the source of competitive advantage. The transition from macro to micro level, induced by technological progress, has resulted in a revised competitive strategy at the global level [4]. Competition is now based on the concept of global city regions [5]. Performance associated with science and technology parks has become global because of the high added value provided by the ICT industry.

Due to the globalization of technology and economy in general, ICT job shifts are occurring worldwide [3]. It is, therefore, important to examine the impact of ICT job shifts all over the world and particularly in developed countries. However, the empirical evidence on this topic is scant [6]. Also, the shift from a macroeconomic to microeconomic perspective has led to the assessment of this phenomenon from a human resources-based view [4].

Multinational companies ("MNCs") have historically favored countries where economies of scale can be achieved. However, their preference criteria have grown to include the presence of organizational and managerial skills and techniques, in addition to the financial gains brought by lower labor costs [7-9]. This has allowed them to establish direct links with the talents with which synergies can develop innovation [10].

\section{Literature Review}

The 'ICT job shifts' phenomenon can be described as the transfer of ICT jobs from developed countries to developing countries. This can be attributed to the globalization of (ICT) jobs where environments conducive to innovation, such as the technological and the scientific parks, become relevant within a business context. The globalization of (ICT) jobs can be defined as a phenomenon of off-shoring or outsourcing jobs to procure human skills and talents $[11,12]$. The globalization of ICT jobs includes job creation and a resulting economic and social prosperity. This approach is based on the creation of enterprises favored by the social connections of talent and exceptional individuals $[5,9,13,14]$. Indeed, the globalization of the ICT industry is not based solely on technological innovation, but also on its location [15]. According to many researchers, location is very important in developing the ICT industry $[5,16,17]$. Combining the late elements, the location, the talent and skills' availability, and a special capability to commercialize innovation allows some regions with their technology parks to be successful.

Various authors and researchers on technological entrepreneurship [18-20] have proposed studies on technological innovation as an evolutionary approach that aims to solve the problem of technological innovation from a cultural perspective and social development $[21,22]$. It can be seen that social connection is a key factor in the development of entrepreneurial activity in technology parks, allowing other countries to gain a competitive advantage in the globalization of trade in technology information and communication. In the Tunisian context, there has, in recent years, been a development of entrepreneurial activity in technology; however, in light of the fact that such entrepreneurial activity is in its early stages, along with the influence that societal and cultural factors play, it will be interesting to see how and to what extent these changing environments of innovation will affect technology parks.

Globalization had an influence on the spread of science and technology, so developing countries are struggling to compete by building capabilities toward gaining the competitive advantage. The ICT job shifts can allow developing countries to gain an advantage

*Corresponding author: Walid Ghodbane, Assistant professor, Department of management science, University of Tunis, Tunisia, Tel: 21650601570; E-mail: 06.waleed@gmail.com

Recieved March 14, 2016; Accepted March 30, 2016; Published April 05, 2016

Citation: Ghodbane W (2016) Challenges of Technological Entrepreneurship in Africa: The Case of Tunisia. J Entrepren Organiz Manag 5: 176. doi:10.4172/2169026X.1000176

Copyright: $\odot 2016$ Ghodbane W. This is an open-access article distributed under the terms of the Creative Commons Attribution License, which permits unrestricted use, distribution, and reproduction in any medium, provided the original author and source are credited. 
by allowing a more specialized workforce that is informed about the technological advancements of the developed countries.

Talents are not easy to find or maintain, and this is where social and cultural factors come into play [7]. For example, Multinational Firms (ICT) seeks to transfer knowledge in technology through the human capital of the host country. Audia and Rider [23] reviewed various theories in psychology regarding organizations and entrepreneurship to examine the notion that entrepreneurs are the products of existing organizations.

\section{Tunisia}

Tunisia has around 700 ICT companies, one-third of which specializes in IT services and engineering. Most of these are small companies, employing fewer than 20 skilled workers. Reselling is the main activity for $45 \%$ of channel partners; $42 \%$ are focused on services, and IT manufacturers represent only $1 \%{ }^{1}$. Tunisia has the most developed telecommunications infrastructure in Africa, and has boosted its IT and telecom sector through some incentives offered to foreign investors, including a 50\% tax break for IT investors, and subsidies and incentives for both hardware and software investments. The public sector also plays an important role ${ }^{2}$. The most important Technology Park is El GhazalaTechnolopole-located in the capital region-followed by Sousse and Sfax. Major investments are planned in telecommunications, with a focus on mobile and internet offerings and data transmission networks. The proposed services include software development, system integration, website design, and network engineering and support. Technology Park El Ghazala in Tunisia is considered a key tool for Tunisia to establish a competitive strategy with the ICT industry. The aim is to provide Tunisia with a place of excellence enabling it to harness the growing opportunities for investment and entrepreneurship in developing new technologies. There are currently more than 90 firms and 12 multinational firm subsidiaries located at the park ${ }^{3}$.

The weaknesses of El Ghazala Technology Park is that it does not currently implement valid assessments of human competencies and talent. Despite internationally standardized ICT infrastructure, El Ghazala Technology Park has two major problems (1) the institutional background and bureaucracy, and (2) the lack of strategic vision and leadership.

At El Ghazala, there is a scarcity of advanced university research labs and they did not develop relationships with industry and the broader economy in general. This might be explained by the nature of the technology parks such that, in El Ghazala, technology parks are MNC oriented, rather than technology-entrepreneurship oriented. Thus the problem is structural specifically, it is created or compounded by the lack of involvement of state agencies and the government. On the one hand, an ecosystem designed for MNC exists which aims to develop their technological activities; on the other hand, there is the need to develop technology entrepreneurship from the ICT jobs created by MNC. Cross-cultural variables such as strength of weak ties and social networks might be able to have a deeper role but only with the support of state-owned agencies and universities.

\section{Methodology}

The present research is partially concerned with the emergence of technology artifacts in a technology park in Tunisia. Specifically, the

\footnotetext{
${ }^{1} \mathrm{http}: / / w w w . t u n i s i e i n d u s t r i e . n a t . t n$

${ }^{2}$ The public sector investments in ICT infrastructure.

${ }^{3} \mathrm{http} / / /$ www.elGhazala.tn
}

novelty of the phenomena associated with artifacts of technology and emerging issues relating to the strategic use of ICT led to the birth of the sub-discipline of information systems. Although the study of entrepreneurship in technology is concerned largely with economic and psychological factors, it is, nevertheless, a field that is suitable for analysis from the perspective of information systems.

The case study is the most appropriate research method in the context of this research, firstly because it is exploratory in nature; secondly, because it is a comparative study of two technology parks and; thirdly, because the research aims to examine a novel (rather than old) phenomenon (namely, ICT job shift globalization).

Yin [24] stressed the importance of distinguishing the case study from other types of qualitative methods, such as ethnography, participant observation, and grounded theory. In particular, he explains that, unlike ethnography, in a case study the researcher does not necessarily go into the field or conduct direct observations of the phenomenon studied and detailed. In general, Yin says that we should not locate the case study in terms of data collection techniques; rather the case study should be regarded as a "comprehensive research strategy "with a" logic design research, data collection techniques and specific approaches in relation to data analysis." However, the case study does possess limitations, the most notable of which relate to representativeness and generalization ${ }^{4}$.

The objective of this research is to examine the role of crosscultural factors in the development of entrepreneurial activity in technology parks. The development of these factors is dependent on the phenomenon of ICT job shifts. This results in the emergence studies, from either single or multiple designs, stems on theory rather than on populations of another phenomenon-namely, the globalization of technology entrepreneurship through technology parks $[25,26]$.

As part of the present research, an assumption of research focuses on test statistics and their interrelationships:

H1: The technology park is a concentration of companies combined, and pursuing goals such as the development of entrepreneurial activity in technology.

H2: Technology Park has a developed infrastructure, including tools for developing

H3: The role of the government is to ensure the sustainability of entrepreneurial activity in technology planning and development Technology Park.

H4: Universities are the core of innovation and creative entrepreneurship. They allow the linking of talents and skills with industry and donors.

H5: The mechanisms of financing are donors who are willing to risk their funds in investment in technological innovations, particularly in startups.

H6: Managerial and technical skills can be acquired from people who have academic training and experience in the field of technology or management.

The foundation of the conceptual model is ICT job shifts, with five elements that are related to ICT clusters: ICT infrastructure, state

${ }^{4}$ The main problem with generalization from studied to unstudied cases is that it is potentially subject to high and unknown levels of error. This problem obviously increases with heterogeneity in the population. (l.e. two different contexts are being compared in Tunisia and in France). According to Yin (1994), generalization of results from case 
agencies, universities, and talents and human competencies. Crosscultural elements are proposed as moderators of the relationship between technology park elements and dependent variables ${ }^{5}(1)$ the entrepreneurial process split into opportunity development and managing the start-up); these cross-cultural variables include: (1) race, (2) ethnicity, (3) gender, and (4) strength of weak and strong ties. Communication and social networks are final moderator elements. The aim is to establish a link between cross cultural variables and the ICT job shifts phenomenon ${ }^{6}$. It is anticipated that the findings from the study will help to explain how ICT jobs are shifted from one ICT cluster to another and how they contribute to sustaining competitive advantage in technology entrepreneurship.

\section{Data}

In order to collect data, semi-structured interviews were administered to the personnel at technology- based companies and research development centers (managers and staff, students, and administration staff). A quantitative questionnaire survey was then designed and administered. Thus, the present study involved a triangulation of methods. Qualitative (interview) data were analyzed using the manual analysis approach [27], and quantitative (questionnaire) data were analyzed using XLStat ${ }^{7}$. Data was collected via an online questionnaire survey and by the researcher's participation in seminars organized by the El Ghazala technology park. Between 2008 and 2011, qualitative data was collected by means of small focus groups ( 5 to 15 people in each group). Focus groups were provided with the same semi-structured questions in order to facilitate the discussion.

\section{Sampling procedure}

The sampling procedure was very simple. First, we reduced data from the qualitative data already collected and this enabled the results to be triangulated. Then, individuals' choices are based on personal profiling ${ }^{8}$. This sampling methodology led us to the sampling procedure. We organized our questionnaire to fit with information needed from our sample as it fits our qualitative research outcomes.

The sample comprised 81 individuals from the El Ghazala Technology Park. This table describes our sampling procedure (Table 1):

\section{Results}

By comparing triangulated results we were able to confirm, in relation to El Ghazala Technology Park, that University/ research laboratories have played only a minor role in establishing bridges with industry, and that there were infrastructure problems (lack of offices

${ }^{5} \mathrm{~A}$ consideration is the relationships moderated by cross-cultural variables. ${ }^{6}$ Cross-cultural variables play a "mediating" role; A mediator variable is a variable that explains (comes in the middle of) the relationship between two variables ${ }^{7}$ http://www.xlstat.com

${ }^{8}$ Personal profiling of selected candidates for our interviews and questionnaire based on (1) Leadership capabilities, (2) importance and influence in entrepreneurs 'community and (3) Availability. and ICT building capabilities). The cross-cultural variables could lead graduate students to find a venture for their ideas. However, it could also impede any initiative or marginalize human talents by fostering the attitude that if anybody takes the initiative it will be against cultural norms and standards. Therefore, Hypothesis 1 is confirmed while hypotheses 2, 3, 4, 5 and 6 are not supported with regard to El Ghazala Technology Park. Indeed, the qualitative results demonstrated that cross-cultural influences on ICT infrastructure, universities and financial mechanisms are very significant.

However, government incentives and efforts are not taking into consideration the endogenous side of technology parks, but it is still significant for entrepreneurial initiative with respect to financial mechanisms as well as the ICT infrastructure. Those initiatives are not coming from the ICT job creation or shifts but, rather, are planned actions from institutions. Thus, it seems that the strategy behind technology park development does not take cross-cultural factors into account. Results (both qualitative and quantitative) provide support for this contention. In El Ghazala, age, gender and ethnicity are the most influential factors in relation to entrepreneurial activity stimulated by ICT job shifts. These findings might best be explained by the fact that MNCs (formed by foreigners, rather than Tunisians or Tunisian Diaspora) are the principal component in El Ghazala.

El Ghazala Technology Park has two telecommunications schools: Supcom ${ }^{9}$ and the ISETcom ${ }^{10}$ for the technicians in the telecommunication industry. The principal mission for both Supcom and ISETcom is to produce technical graduates and prepare students to embark on a career in the IT sector (Tables 2 and 3).

There are two state agencies in El Ghazala Technology Park among the administration: (1) CERT and (2) ANCE. They depend on their department of origin: the national telecom operator for the first agency and the ministry of telecommunication and defense for the second (Tables 4-8).

\section{Conclusion}

Entrepreneurship is created by innovation and business initiative woven with risk taking strategies. One of the novel ways of doing business is Technology entrepreneurship. Technology entrepreneurship is based on some important steps to establish business ventures, such as: following the patterns and efficacy of existing Technology Parks, identifying the prospective regions, human capital equipped with ICT skills, social interactions with corporations, operational financial resources, productivity, adoption of policies and best management practices.

Technology entrepreneurship in Africa and especially Tunisia faces huge challenges to operate successfully. The major hurdles are ICT policies, regional infrastructure to promote business, identifying skilled human labor, and technology and product promotion.

9 http://www.supcom.mincom.tn

$10 \mathrm{http}: / / \mathrm{www}$.isetcom.mincom.tn

\begin{tabular}{|l|l|l|l|}
\hline Sample & Description & Extraction and Representativeness & The use of PCA methodology \\
\hline EI Ghazala & The sample is composed of 81 respondents: & At El Ghazala Technology & Moderator variables \\
(EG) & -15 CEO, MNCrepresentatives. & $\begin{array}{l}\text { Park, the sample was extracted and then selected } \\
\text { (cross-cultural factors) are confirmed to have }\end{array}$ \\
& $\begin{array}{l}-55 \text { prospective technology entrepreneurs. } \\
\text { in the basis of technology 10 entrepreneurship } \\
\text { process }^{2} .\end{array}$ & a high impact on ICT job shifts ${ }^{3}$.
\end{tabular}

${ }^{1}$ Employees of the technology park el ghazala including the two agencies for telecom and electronic certification.

${ }^{2}$ Selection of relevant profiles for our questionnaire was based on the assessment made by qualitative methodology. Respondents who are close to Graduate, seeking "opportunities" was given a special attention.

${ }^{3}$ See appendix 4 (i.e., el ghazala statistics) Contribution of the variables (\%) and Squared cosines of the observations.

Table 1: Sampling procedure description and use of PCA methodology. 
Citation: Ghodbane W (2016) Challenges of Technological Entrepreneurship in Africa: The Case of Tunisia. J Entrepren Organiz Manag 5: 176. doi:10.4172/2169-026X.1000176

Page 4 of 6

\begin{tabular}{|c|c|c|c|c|c|c|}
\hline \multirow[t]{2}{*}{ Universities } & \multicolumn{5}{|c|}{ Moderator variables } & \multirow{2}{*}{$\begin{array}{l}\text { ICT job shifts } \\
\text { Impacts }\end{array}$} \\
\hline & Code & SWT & ETH. RACE. Gender & $\begin{array}{l}\text { Communication Social } \\
\text { Networks }\end{array}$ & Research Propositions ${ }^{1}$ & \\
\hline SUPCOM & SCOM & Strong & $\begin{array}{l}\text { No ethnic or racial } \\
\text { problems }\end{array}$ & Fair researcher communities & P1, P2, P6 OK P3, P4, P5 Non confirmed & Strong \\
\hline ISETCOM & ICOM & weak & Female challenges & Poor job prospects & $\begin{array}{l}\text { P1, P2, P3, P4 confirmed P5, P6 non } \\
\text { confirmed }\end{array}$ & Moderate \\
\hline \multicolumn{7}{|c|}{$\begin{array}{l}\text { Note: SWT=Strength of Weak Ties } \\
\text { 'P1: spin-off and start-ups arise from an ecosystem of skills of highly qualified academic and professional human resources. } \\
\text { P2: the technology park objective is to develop entrepreneurship through the ICT job shifts phenomenon. } \\
\text { P3: managerial skills and techniques influence the interaction between businesses in the technology park. } \\
\text { P4: the development perspective of the ICT job shifts depends on technology entrepreneurs. } \\
\text { P5: Cross-cultural factors influence the establishment of a technological trajectory between technology parks, including those of France and Tunisia. } \\
\text { P6: the development of entrepreneurial activity depends on the underbody of cross-cultural technology entrepreneurs. The location of technology parks, including El } \\
\text { ghazala in Tunis-Tunisia- and Sophia Antipolis in Nice-France- contribute to the emergence of the technology entrepreneurship process. }\end{array}$} \\
\hline
\end{tabular}

Table 2: Role and impact of cross-cultural variables on universities.

\begin{tabular}{|c|c|c|}
\hline University & Themes & Interpretations \\
\hline & Educational role of university. & $\begin{array}{l}\text { The management role of university is dominant in the educational purpose of university. This role is very important for } \\
\text { engineers and MNC present in thetechnology park el Ghazala. University has an educational role and "institutional" } \\
\text { one by delivering their student an engineer diploma after finishing their studies. Cross-cultural variables are very } \\
\text { significant in this university. As education is open and free for all, the access and the success are based on "diploma" } \\
\text { itself. The entrepreneurial role of academia and scientific research is minimal. }\end{array}$ \\
\hline \multirow[t]{2}{*}{ SUPCOM } & $\begin{array}{l}\text { Entrepreneurial } \\
\text { role of University. The } \\
\text { knowledge diffusion. }\end{array}$ & $\begin{array}{l}\text { The entrepreneurship process is very complex to establish within university. However, it seems that knowledge diffusion } \\
\text { plays an important role in the technology transfer for established companies and MNC. This transfer is very weak as } \\
\text { the relationship between university and industry is not well defined and clear. }\end{array}$ \\
\hline & $\begin{array}{l}\text { Aspiring role of university } \\
\text { teaching programs to apply the } \\
\text { knowledge gained and identify } \\
\text { opportunities }\end{array}$ & $\begin{array}{l}\text { This sub-variable is related to the appropriateness of technology education and its outcomes. We categorized this } \\
\text { sub-variable from different sources and we found that knowledge diffusion at educational level does not play a role in } \\
\text { the entrepreneurial process. Furthermore, MNC has established standards and norms by which they catch the sticky } \\
\text { knowledge in the educational background of engineers. Thus, the role of the university as an entrepreneurial "hub" } \\
\text { does not work. }\end{array}$ \\
\hline ISETCOM & Employment prospects & $\begin{array}{l}\text { Students link their education with their first employment. This sub-variable demonstrates that employment and success } \\
\text { in finding a job after graduating is very important for students. As employment prospects for ISETCOM students are } \\
\text { limited to MNC and some established companies outside the technology park, unemployment problems arise. The } \\
\text { student does not see entrepreneurial opportunity because there are no associations or organizations that support } \\
\text { entrepreneurship inside the technology park. }\end{array}$ \\
\hline
\end{tabular}

Table 3: Results relating to the role cross-cultural variables in technology entrepreneurship development in the university.

\begin{tabular}{|c|c|c|c|c|c|c|}
\hline State Agencies & & & & Moderator Variables & & ICT Job Shifts \\
\hline & Codes & SWT & Ethnicity; Race; Gender & Communication Social Networks & Research Propositions & Impacts \\
\hline ANCE & ANCE & Strong & $\begin{array}{l}\text { No ethnic or racial } \\
\text { problems }\end{array}$ & $\begin{array}{l}\text { strong influence of internet } \\
\text { (bandwidth) }\end{array}$ & $\begin{array}{l}\text { P1, P2, P3, P5 OK P4, P6 Non } \\
\text { confirmed }\end{array}$ & Very significant \\
\hline CERT & CERT & Weak & Female challenges & No effective role & $\begin{array}{c}\mathrm{P} 1, \mathrm{P} 2, \mathrm{P} 3, \mathrm{P} 4 \text { confirmed P5, P6 non } \\
\text { confirmed }\end{array}$ & Non-Significant \\
\hline
\end{tabular}

Table 4: Mixed impacts of cross-cultural variables and state agencies on technology entrepreneurship.

\begin{tabular}{|l|l|l|}
\hline State agencies & Themes & Interpretations
\end{tabular}

Role of state's agencies in fostering Factor of development While the institutions of El Ghazala are very weak and with no incidence on technology entrepreneurship, technology entrepreneurship in el of entrepreneurial the telecom valley organization is very influential in this respect. Hence, the development of the Ghazala technology park: ANCE and opportunity $\quad$ entrepreneurial opportunity is blocked by institutional barriers in Tunisian techno park.

CERTcom $\begin{array}{lll}\text { Problems faced by } & \text { There are some problems faced by entrepreneurs. At El Ghazala we found that cross-cultural variables are } \\ \text { new firms in the park. } & \text { very influential. However, they are not managed sufficiently to attract and retain new entrepreneurs. }\end{array}$

Table 5: The role of state agencies in technology entrepreneurship development with ICT job shifts

During data collection, the research team had the opportunity to meet with several individuals in the ICT domain. These people are directly or indirectly involved in the entrepreneurial ecosystem of El Ghazala.

\begin{tabular}{|c|c|c|c|c|c|c|}
\hline \multirow{2}{*}{$\begin{array}{l}\text { Technical and Managerial } \\
\text { Competencies }\end{array}$} & \multicolumn{5}{|c|}{ Moderator Variables } & \multirow{2}{*}{ ICT Job Shifts } \\
\hline & Codes & SWT & Ethnicity; Race; Gender & $\begin{array}{l}\text { Communication Social } \\
\text { Networks }\end{array}$ & Research Propositions & \\
\hline Technical competencies & TOCO M & Strong & $\begin{array}{l}\text { No ethnic or racial } \\
\text { problems }\end{array}$ & Strong & $\begin{array}{c}\mathrm{P} 1, \mathrm{P} 2, \mathrm{P} 3, \mathrm{P} 5 \mathrm{OK} \text { P4, P6 Non } \\
\text { confirmed }\end{array}$ & Strong \\
\hline Managerial competencies & MCOM & Strong & Female challenges & Fair & $\begin{array}{c}\text { P1, P2, P3, P4 confirmed P5, P6 non } \\
\text { confirmed }\end{array}$ & Strong \\
\hline
\end{tabular}

Table 6: The impacts of cross-cultural variables in technical and managerial skills: The role of Universities in creating ICT job shifts. 


\begin{tabular}{|l|l|l|}
\hline Sub-Sample & Themes & Interpretations \\
\hline Students & Culture and skills & $\begin{array}{l}\text { The ICT talents are very important to foster technology entrepreneurship. The cross-cultural variables impact the students' path. } \\
\text { The consequence of culture and lack of efficient institutions drive EI Ghazala university students to search for employment rather } \\
\text { than searching for an entrepreneurial opportunity. }\end{array}$ \\
\hline $\begin{array}{l}\text { Special } \\
\text { ecosystem }\end{array}$ & $\begin{array}{l}\text { The special ecosystems that drive innovation and entrepreneurship are impacted by cross-cultural variables. We argue that EI } \\
\text { Ghazala requires institutional support and social mechanisms that help create and prepare students to be entrepreneurs and } \\
\text { take initiative. }\end{array}$ \\
\hline $\begin{array}{l}\text { Managers (both } \\
\text { technical and } \\
\text { managerial } \\
\text { competencies) }\end{array}$ & $\begin{array}{l}\text { Experience } \\
\text { and extra } \\
\text { professional } \\
\text { activities }\end{array}$ & $\begin{array}{l}\text { Experience influences the engineers and ICT managers. At El Ghazala we met with ICT technical and managerial staff of all } \\
\text { levels. It seems that the cross-cultural variables such as strength of strong ties and communication are related to the academic } \\
\text { background. }\end{array}$ \\
\hline
\end{tabular}

Table 7: Influence of cross-cultural variables on ICT job shifts and ICT skills and talents in EI Ghazala.

Cross tab analysis was used to summarize the statistical findings. The main statistical instrument was principal component analysis or PCA which was conducted in order to conceptualize important variables for use in testing the hypotheses.

\begin{tabular}{|c|c|c|}
\hline Variables & El Ghazala-Tunisia & \\
\hline \multirow{2}{*}{ ICT infra- structure } & Hypothesis & Cross-cultural variables' impacts \\
\hline & H2- Non confirmed ${ }^{1}$ & $\begin{array}{l}\text { The role of university is very significant with the cross-cultural variables. The ICT infrastructure is negatively influenced by the } \\
\text { ICT job shifts. Race, SWT, communication and social networks are influencing the ICT infrastructure positively; ethnicity, age } \\
\text { and gender are influencing this variable negatively. This can be interpreted as a threat to entrepreneurship development in the } \\
\text { technology park EI Ghazala, because of the quality of ICT infrastructure that does not encourage technology entrepreneurship. } \\
\text { Younger students and researchers need an up-to-date ICT infrastructure. ICT job shifts are influenced by cross-cultural } \\
\text { variables and by ICT infrastructure. At EI Ghazala this influence is negative. It means that ICT infrastructure impedes technology } \\
\text { entrepreneurship initiatives. }\end{array}$ \\
\hline State agencies & H3-Supported ${ }^{2}$ & $\begin{array}{l}\text { Age, gender and communication play a positive role with 'State agencies'. However, race, SWT and social networks have a } \\
\text { negative impact on it. This is due to the nature and the role assigned to the state agencies. Indeed, the PCA, previous results, } \\
\text { has supported it. }\end{array}$ \\
\hline \multirow[t]{2}{*}{$\begin{array}{l}\text { Human talents and } \\
\text { competencies }\end{array}$} & $\mathrm{H} 1, \mathrm{H} 6$ & $\begin{array}{l}\text { Age, gender and social networks positively influence technology entrepreneurship with the help of the ICT job shifts. (The PCA } \\
\text { results demonstrate that those variables are very influential in regard to technical and human competencies). }\end{array}$ \\
\hline & $\begin{array}{l}\text { H1 supported. H6 is } \\
\text { not supported }\end{array}$ & $\begin{array}{l}\text { The results of the linear regression analysis demonstrated that race, age, gender and social networks are helping to implement } \\
\text { efforts to build human talents capabilities. However, SWT and communication are negatively influencing the role of the } \\
\text { technology park in dealing with the strategic use of human capital. There is no special ecosystem that could help build this } \\
\text { strategic capability. }\end{array}$ \\
\hline Universities & H4 Not supported ${ }^{4}$ & $\begin{array}{l}\text { Race, gender and age have a positive impact through universities at El Ghazala Technology Park. Communication, social } \\
\text { networks and ethnicity play a negative role in establishing entrepreneurial linkages between university and MNC. This is due } \\
\text { to the role of research facilities based in both isetcom and supcom. Communication is very weak and social capital is not } \\
\text { appreciated. Universities are marginalized because of the lack of vision. Research labs are influenced by race, gender and } \\
\text { age. This constitutes an opportunity to get hold of universities at El Ghazala technology park. }\end{array}$ \\
\hline Summary & $\begin{array}{l}\text { H1supported } \\
\text { H2,3,4,5,6 } \\
\text { Not supported }\end{array}$ & $\begin{array}{l}\text { We tested the impact of seven cross-cultural variables upon the dependant variables in our conceptual model. The use of PCA } \\
\text { as a statistical exploratory tool helped us to confirm that independent variables (cross-cultural) have a strong impact upon } \\
\text { the dependant variables (elements of the technology park). At EI Ghazala technology park we pointed out three main issues } \\
\text { (1) university/ research labs play a very minor role in helping establish bridges with industry, (2) financial mechanisms are } \\
\text { limited (this is a real challenge for technology entrepreneurs), and (3) infrastructure problems ( lack of offices and ICT building } \\
\text { capabilities). The cross-cultural variables could help graduate students to find a venture for their ideas. However, it could also } \\
\text { slow down any initiative or marginalize human talents by conveying the message that if anybody take the initiative it will be } \\
\text { against cultural references and standards. }\end{array}$ \\
\hline \multicolumn{3}{|l|}{$\begin{array}{l}\text { 1See appendix } 2 . \\
\text { 2See appendix } 5 . \\
{ }^{3} \text { See appendix } 4 \\
{ }^{4} \text { See appendix } 3\end{array}$} \\
\hline
\end{tabular}

Table 8: Results of the cross tab analysis.

The study demonstrates a strong relationship between cross-cultural variables and technology entrepreneurship development. However, in Tunisia the ICT infrastructure problems might be impeding progress in the further development of the technology park at El Ghazala.

In the light of present study and in order to overcome the major barriers found in this sector, we recommend that El Ghazala Technology Park should develop its existing financial mechanisms; enhance competitive edge over technology parks by employing cross cultural variables; project the contribution of States agencies; adopt effective communication channels; formulate Technology entrepreneurship incentives; explore technology outsourcing possibilities by coordinating with corporate and leadership should play a visionary role to uplift the global ICT market.

Future research should include studies of Technology Parks should focus on their institutional or managerial weaknesses undermining their potential growth. The Governments should support for basic science in Universities. In fact, regions with ICT capable of human capital should be explored without any racial and gender bias. Research on public-private partnerships and their impact on technology entrepreneurship should be established for emerging applied technologies. Other research considerations are the leadership contribution to the ICT strategy based on Technology Park development, with the purpose of advancing science and technology and sustenance of global economy.

\section{References}

1. Porter M (1990) The Competitive Advantage of Nations. The Free Press, New York pp: 255-364.

2. Porter M (1998) Clusters and Competition, in On Competition. Harvard Business School Press, Cambridge 7: 197-271. 
Citation: Ghodbane W (2016) Challenges of Technological Entrepreneurship in Africa: The Case of Tunisia. J Entrepren Organiz Manag 5: 176. doi:10.4172/2169-026X.1000176

Page 6 of 6

3. Porter M (1998) Clusters and new economics of competition. In On Competition, Harvard Business School Press, Cambridge pp: 77-90.

4. Porter ME, Et Stern S (1999) Understanding the Drivers Of National Innovative Capacity. MIT Sloan School p: 10.

5. Scott AJ (2001) Global City-regions: Trends, Theory, and Policy. Oxford University Press pp: 137-169.

6. Bernhard M (2007) Potential ICT-enabled Offshoring of Service Jobs in Belgium. Federal Planning Bureau, Kunstlaan/Avenue des Arts 47-49, 1000 Brussels pp: 1-16.

7. Andersen PH, Christensen PR (2005) From localized to corporate excellence: How do MNCs extract, combine and disseminate sticky knowledge from regional innovation systems? DRUID Working Paper pp: 05-16.

8. KohFrancis CC, Winston TH K, Feichin TT (2005) An analytical framework for science parks and technology districts with an application to Singapore." Journal of Business Venturing 20: 217-239.

9. Steve L (2007) Silicon Valley Shaped by Technology and Traffic, New York Times p: 5.

10. Chesbrough H, Vanhaverbeke W, West J (2006) The inter-organizational context of open innovation. Open innovation researching a new paradigm $\mathrm{pp}$ : 1-22.

11. Saxenian AL (2000) Silicon Valley's New Immigrant Entrepreneurs, The Center for Comparative Immigration Studies. University of California, San Diego, Working Paper pp: 1-30.

12. Martin R, Aldrich HE, Carter N (2003) The structure of organizational founding teams: Homophile, strong ties, and isolation among US entrepreneurs. American Sociology Review 68: 195-222.

13. Granovetter M (1985) Economic action and social structure: the problem of embeddedness. American Journal of Sociology 91: 481-510.

14. Granovetter M (2005) The Impact of Social Structure on Economic Outcomes. Journal of Economic Perspectives 19: 33-50.

15. Florida R (2002) The economic geography of talent. Anals of the association of the American geographers 92: 743-755.
16. Moretti E (2012) The New Geography of Jobs. Houghton Mifflin Harcourt Edn p: 304.

17. Van Der Linde C (2003) The Demography of clusters: Findings from the cluster Meta-Study. Innovation, Clusters and interregional competition, Berlin, Heidelberg, Springer-Verlag, New York pp: 130-149.

18. Zahra SA, Gerard G (2002) International entrepreneurship: The current status of the field and future research agenda. Entrepreneurship Theory and Practice 41: 50 .

19. Richtermeyer G (2003) Emerging themes in entrepreneurship research, Business Research and Information Development Group (BRIDG). Outreach and extension, University of Missouri, Lincoln University p: 29.

20. Zahra S, Bogner W (2000) Technology Strategy and Software New Venture Performance: The Moderating Effect of the Competitive Environment. Journal of Business Venturing 15: 135-173.

21. Florida $R$ (2002) The rise of the creative class. Basic Books, NY, USA.

22. Parnell JA (2006) Global Entrepreneurial Strategy. In: Carraher (ed.) International Entrepreneurship.

23. Audia PG, Rider $\mathrm{Cl}$ (2005) Entrepreneurs as organizational products: Revisited. Robert Baum, Michael Frese, and Robert Baron (eds.) University of California, Berkeley pp: 1-33.

24. Yin RK (2003) Case Study Research. (3rdedn) Sage Publications, London, England.

25. Schramm C, Ballmer S, Bernd D, Blanchard J, Buckley G (2008) Innovation measurement: tracking the state of innovation in the American economy: A report to the US secretary of commerce. Kauffman Symposium on Entrepreneurship and Innovation Data pp: 1-19.

26. Athreye S (2010) Economic Adversity and Entrepreneurship-led Growth Lessons from the Indian Software Sector. World Institute for Development Economics Research (UNU-WIDER) pp: 1-20.

27. Miles MB, Huberman AM (1994) Qualitative Data Analysis. (2ndedn) Newbury Park, CA, Sage pp: 10-12. 